\title{
Enzymes, Dentinogenesis and Dental Caries: a Literature Review
}

\author{
Markku Larmas ${ }^{1}$, George K. B. Sándor ${ }^{2}$ \\ ${ }^{1}$ Department of Pediatric Dentistry and Cariology, Institute of Dentistry, University of Oulu, Oulu, Finland. \\ ${ }^{2}$ Department of Oral and Maxillofacial Surgery, Institute of Dentistry, University of Oulu, Oulu, Finland.
}

\section{Corresponding Author:}

Markku Larmas

Department of Pediatric Dentistry and Cariology, Institute of Dentistry

University of Oulu

Aapistie 3, 900014, Oulu

Finland

Phone: +358405167516

Fax: +35885375504

E-mail: dottorbarone@gmail.com

\begin{abstract}
Objectives: Search in PubMed with keywords "enzymes, dentinogenesis, and dental caries" revealed only 4 items, but when combined with "enzymes, osteogenesis, and osteoporosis" as high as 404 items resulted. Dental caries was associated with an order of magnitude fewer studies than the chronic bone disease, osteoporosis. This observation motivated this review.

Material and Methods: A comprehensive review of the available literature on role of enzymes in dentinogenesis and dental caries was undertaken using MEDLINE (PubMed) and Scopus. Keywords for the search were: enzymes and odontoblasts, enzymes and different forms of dentinogenesis as well as dental caries.

Results: Search revealed studies which described odontoblasts harbouring numerous enzymes (hydrolases, including metalloproteinases, transaminases and dehydrogenases) during primary dentinogenesis. Alkaline phosphatase activity sharply decreased when odontoblasts turned into quiescent odontoblasts. Tertiary dentinogenesis was characterized first by reactionary dentine formation when alkaline phosphatase was highly reactivated. Then later some of these odontoblasts may die out and be replaced by other progenitor cells of pulpal origin. This tertiary dentine was called reparative dentine. Pulpal progenitor/stem cells revealed alkaline phosphatase activity in areas encircling inflamed pulp sections. Soft carious dentine revealed high hydrolase, transaminase and dehyrogenase activities that may have originated from invading microbes, saliva or were endogenous. Proteolytic activity was especially demonstrable using histochemical and biochemical means. Specifically, matrix metalloproteases may have originated partly from activated proenzymes of host origin.
\end{abstract}

Conclusions: Though dental studies are scanty when compared to bone, the active role of large spectrum of enzymes in healthy and carious dentine was given support.

Keywords: dental caries; dentinogenesis; dentine; enzymes.

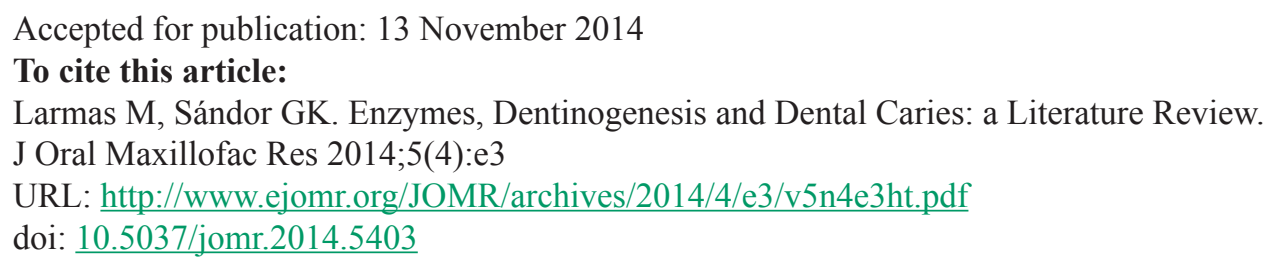




\section{INTRODUCTION}

\section{Comparison of dentine and bone in health and disease}

Research on medical tissues in health and disease (bone and osteoporosis) is at least a magnitude more vivid than that in dentistry (dentine and caries).

Dental caries was the reason for the establishing the first Dental School in Baltimore, USA in the mid of 18th century. This review article is an attempt to shed light on the role of enzymes during dentinogenesis and dentine steady state in health and caries taking models of enzyme functions from bones.

\section{Embryology of teeth}

Ectoderm covering the stomodeum of an embryo begins to proliferate, giving rise to dental laminae, which occurs in humans during the sixth week in utero. Reciprocal interactions between the ectoderm and mesoderm layers lead to placode formation, some of which develop into tooth germs, containing an enamel organ, dental papilla, and dental follicle. Therefore, teeth are made of ectodermal (enamel organ) and ecto-mesenchymal components, containing neural crest-derived cells, which display multipotent capabilities [1].

Dental pulp is externally separated from dentine by odontoblasts and by Höhl's subodontoblastic cells which are preodontoblasts [2]. Adjacent to this layer, the pulp is rich in collagen fibbers and poor in cells. Then a more internal layer contains progenitor cells and undifferentiated cells, some of which are considered stem cells [3]. The innermost layer is the core of the dental pulp and comprises the vascular plexus and nerves but some nerve branches and capillary vessels reach the odontoblast layer.

The final differentiation of tooth-forming cells, as well as matrix secretion and mineralization, takes place in the bell-stage. The junction between the dental papilla and inner enamel epithelium determines the final crown shape and size of a tooth. Odontoblasts secrete a collagenous matrix, called predentine and at the onset mantle dentine, later term being dentine, which is then mineralized during primary dentinogenesis.

\section{Primary, secondary and tertiary dentinogenesis}

Primary dentinogenesis in humans is completed when the tooth becomes functional and contacts are established between maxillary and mandibular teeth by late adolescence or early adulthood when it turns into secondary dentinogenesis. Nonproliferative odontoblasts reduce the speed of deposition or, may enter the quiescent state and may remain quiescent during their lifetime. Therefore, the term "postmitotic" is often used to refer to both quiescent and senescent odontoblasts.

Some cellular features of odontoblasts change when primary dentinogenesis turns into secondary but nevertheless, these cells maintain the same denomination. Odontoblast is a nomenclature which has been established by Waldeyer as early as in 1885 .

Odontoblasts maintain their capacity of secreting dentine throughout life. The suffix "cyte" is employed in mineralized tissues to designate the quiescent stage of a cell that previously underwent an active secretory stage and then remained surrounded by the mineralized matrix like osteocytes and cementocytes. However, in living cells, only the speed of deposition varies between the blast- and cyte- phases.

One exception exists: the cells of the growth plates of long bones proliferate rapidly and are termed chondrocytes, until they undergo apoptosis at the latest when the youngster turns into an adult [4]. The suffix "cyte" is now used in mitotic cells. In puberty, both the growth of humans and the elongation of their tooth roots will halt. While the dividing chondrocytes inside the mineralized matrix of bones go through apoptosis and disappear, the odontoblasts which become quiescent are not renamed odontocytes.

The present nomenclature may change in the future: recently Larmas and Sándor [4] suggested that odontoblasts during secondary dentinogenesis should be renamed as "odontocytes". Most mammalian teeth cease their elongation at the cessation of root formation. In some teeth, however, transdifferentiation from odontoblasts to odontocytes does not happen, which would explain why some mammalian teeth (elephant tusks and rodent incisors) are ever-growing [4].

During tertiary dentinogenesis, which is not physiological and occurs in response to a local stimulus, the situation changes again: the resting odontoblasts/odontocytes may return to an activated stage (forming reactionary dentine) and/or die out and may be replaced by other cells of pulpal origin. In this case tertiary dentine is then called reparative dentine (Table 1).

Do adult odontoblasts transdifferentiate into "odontocytes" in teeth with closed root apices [4], or are they then "secondary odontoblasts" and after injury "tertiary odontoblasts" or "reactionary odontoblasts" as Simon et al. [] suggest, or are they then "resting" or "old" odontoblasts" as reported in textbooks [] This textbook nomenclature is based on the original observations of Couve [7] in growing teeth in humans and confirmed recently also in adult teeth $[\underline{8}, \underline{9}]$. 
Table 1. Stages of dentinogenesis, cells, and enzymes involved in it

\begin{tabular}{l|c|c|c|c|c}
\hline \multirow{2}{*}{} & \multicolumn{4}{|c}{ Stages of dentinogenesis } \\
\cline { 2 - 5 } & Bell stage & $\begin{array}{c}\text { Primary } \\
\text { dentinogenesis }\end{array}$ & $\begin{array}{c}\text { Secondary } \\
\text { dentinogenesis }\end{array}$ & \multicolumn{2}{c}{ Tertiary dentinogenesis } \\
\cline { 5 - 6 } Cells & $\begin{array}{c}\text { Ectomesodermal stem/ } \\
\text { progenitor }\end{array}$ & Odontoblasts & Odontocytes & $\begin{array}{c}\text { Activated } \\
\text { odontocytes }\end{array}$ & $\begin{array}{c}\text { Pulpal stem/ } \\
\text { progenitor }\end{array}$ \\
\hline Enzymes & Multiple & High APase & Low APase & High APase & High APase \\
\hline
\end{tabular}

\section{MATERIAL AND METHODS}

Since there were no interventions or randomized controlled trials involving the role of enzymes during dentinogenesis and dentin steady state identified in a preliminary literature search, the Preferred Reporting Items for Systematic Reviews and Metaanalysis (PRISMA) statement [10] or Cochrane Handbook [11] were not used in this review. Instead the following search protocol was employed. Literature was selected through searches in PubMed and Scopus databases. The keywords used for the searches (in August, 2014) were "Enzymes" and "Odontoblasts". Only articles written in English were included and their number restricted to enzymes, dentinogenesis and caries: Ultimately a manual search of English language dental anatomy and textbooks was performed.

Using key words "Enzymes" and "Odontoblasts" PubMed hits were 598 while Scopus hits were 371. Using "Enzymes" and "Dental caries" Pubmed yielded 1301 hits while Scopus produced 988 hits. Key words "Enzymes" and "Dentine caries" in Pubmed gave 179 hits and Scopus had 100 hits. "Enzymes" and "Enamel caries" in Pubmed resulted in 131 hits while Scopus gave 81 hits. "Enzymes" and "Dentinogenesis" in Pubmed resulted in 183 hits while with Scopus there were 91 hits. Using key words "Enzymes" and "Primary dentinogenesis" there were 18 hits in Pubmed and in Scopus there were 8. "Enzymes" and "Secondary dentinogenesis" gave 20 hits in Pubmed and 8 hits in Scopus. "Enzymes" and "Tertiary dentinogenesis" gave only 6 hits in Pubmed and 2 in Scopus. Scopus gave a total of 100 hits for "Enzymes" and "Dentine caries" and those were reported as follows: Larmas 14, Mäkinen 9, and Tjäderhane 8, all authors being from the same research group. When the English language search was restricted to "Enzymes", "Dentinogenesis" and "Caries" then only 3 - 4 hits were produced by Pubmed and Scopus respectively. Additionally, a manual search in dental anatomy and dental textbooks were performed. Presently the review covers 51 references.

\section{RESULTS \\ Cellular events in the early differentiation phases}

The final differentiation of the tooth-forming cells from embryonic progenitor/stem cells take place in the bell stage of tooth development. The bell stage is known for histo-differentiation and morphodifferentiation. The enamel organ is bell-shaped during this stage. The columnar cells of the enamel organ adjacent to the dental papilla are known as the inner enamel epithelium, which are differentiated from stem cells of inner enamel epithelium, or ameloblasts, as they move outwards or upwards. Ectomesodermal stem cells differentiate into odontoblasts and secrete a collagenous matrix which is then mineralized into extracellular dentine.

Enamel formation that also regulates dentinogenesis occurs in two phases. First, the enamel-forming ameloblasts secrete an organic matrix that is then mineralized. Thereafter, during a distinct stage called enamel maturation [12], a sudden and massive influx of mineral ions takes place. The maturation stage initiates in the cusps while the secretory phase continues in the more cervical parts of the enamel organ.

\section{Enzymes in undifferentiated dental cells}

In order to reach an integrated picture of cell metabolism at the onset of tooth ontogeny, several histochemical studies have been performed on enzymes in cells and structures in experimental animals. Enzymes participating in cell metabolism are normally demonstrable at the stage of active differentiation, but also in differentiated tooth forming cells. However, it should be considered that quantification of enzyme activity by histochemical means is impossible because changes in enzyme activity may represent a direct change in the number of enzyme molecules, alterations in the physical state of the enzyme molecules or the effects of various co-factors in addition to technical assay problems. 
Histochemical studies of differentiating, developing and forming human teeth and supporting structures have also been performed. Several arylaminopeptidases and glucosidases were demonstrated in the basal cell layer of stomodeum, in the subjacent mesoderm, in the outer and inner enamel epithelium, in the dental papilla and lamina, and in the primordium of permanent tooth [13]. No arylaminopeptidase activity could be observed in ameloblasts, odontoblasts, enamel, dentine, stellate reticulum, and pulp, and the inner enamel epithelium also lost its activity during the stage of apposition.

All structures (except enamel and dentine) of the human tooth germ revealed dehydrogenases including lactate $(\mathrm{LDH})$, succinate $(\mathrm{SDH})$, glutamate $(\mathrm{GDH})$, and $\mathrm{NADH}_{2}$ activities in different patterns [14]. LDH activities decreased during the development in the epithelium and the subjacent mesoderm up to the stage of apposition, when ameloblasts and odontoblasts revealed intense $\mathrm{LDH}$, weak $\mathrm{SDH}$ activity, and strong $\mathrm{NADH}_{2}$ - diaphorase activity [14]. These observations suggested that anaerobic glycolysis as an energy source dominated in mineralizing cells at the onset of enamel and dentine formation.

Histochemical analyses are essential for understanding the localization of molecules, and biochemical studies are needed for the demonstration of real changes in enzyme activity. In experimental mice, a considerable rise in the membrane-bound enzyme, non-specific alkaline phosphatase (APase) activity in the mesenchymal part of tooth germs between the $18^{\text {th }}$ prenatal day and the $1^{\text {st }}$ day was seen [15]. That time corresponds to the onset of mantle dentine secretion by odontoblasts in mice. Because the protein content of the samples also increased during this 2-day period, it seems that reactions catalyzed by APase are stimulated at that stage. This stimulation further increased up to the $7^{\text {th }}$ day, after which the protein content dramatically decreased in 4 days and the APase activity in 10 days, indicating that the stimulation period of APase activity in mesenchyme had ended.

The secretion of enamel in mice molars starts between the $1^{\text {st }}$ and $2^{\text {nd }}$ postnatal days, at which time the increase in epithelial APase becomes pronounced and continues up to the $7^{\text {th }}$ day. The observed changes in APase activity in both ectodermal and ectomesenchymal parts of the tooth germs could be due to changes in the number of cells associated with the synthesis and/or activation of APase molecules [15]. Epithelial and mesenchymal parts of teeth could not be isolated at day 11, when the mice molars had not emerged, but their crown development was complete.
Then a significant decrease in the APase activity was seen in the mesenchyme [15]. Because the mineralization of dentine matrices closely follows the secretory phase, the role of APase in either secretion or mineralization cannot be distinguished. The developmental stage in the cusp region is more advanced than in the cervical part. Thus, the role of APase can be linked to both of these phenomena.

The activity of matrix metalloproteinases (MMPs), a class of $\mathrm{Ca} / \mathrm{Zn}$-dependent endopeptidases that remain trapped within the mineralized dentine matrix, is regulated by members of the TIMP (tissue inhibitors of metalloproteinase) family. The expression of gelatinase A (MMP-2) and gelatinase B (MMP-9) as well as TIMP-1, -2 and -3 genes during different stages of mouse tooth development was analyzed [16]. Gene expression was generally found in mesenchymal tissues except for TIMP-3, which also was found in dental epithelial cells. Gelatinase B and TIMP1 and TIMP-3 expression showed clear association with epithelial morphogenesis and was restricted to the mesenchyme at the tip of the growing tooth bud. Gelatinase A and TIMP-1 showed transient expression in secretory odontoblasts at the time of basement membrane degradation, while TIMP-2 expression continued throughout the dental papilla [16].

\section{Cellular events in primary dentinogenesis}

During primary dentin formation, odontoblasts retreat from the mineralization front, leaving behind cellular processes that remain trapped in dentinal tubules. Active odontoblasts are under hormonal regulation. For example, estrogen deficiency, induced by ovariectomy, caused enhanced dentine formation in adult rats, suggesting that estrogen receptors may be present also in dental tissues [17].

Odontoblasts are reported to reveal the expression of mineralization-related genes, including dentine sialophosphoprotein and dentine matrix protein-1 [18-20]. Odontoblasts are dividing in the elongating permanent tooth until the closure of the root apex. After apical closure old odontoblasts or odontocytes continue to maintain their vital functions during secondary dentinogenesis, which maintains the mechano-modulatory role in adult dentine with a very low rate of dentine formation but contrary to bone, without dentine resorption.

The areas of a developed caries lesion and formed dentin under the lesion during the cariogenic challenge positively correlated in all molars up to 7 weeks after weaning of the rat pup [21]. Then a dramatic drop in both the rate of caries progression and that of dentine formation was seen 
when compared to adult rats. The rate of progression was only one tenth of that in primary dentinogenesis [22]. Thus, the rate of caries progression and that of dentinogenesis is related [르] .

Some genetic disorders may be linked to the stages of odontoblast differentiation such as dentinogenesis imperfecta in which teeth are blue-brown colour with pulp obliteration or large pulp chambers. Type I dentinogenesis imperfecta occurs in people who have some form of osteogenesis imperfecta. Dentinogenesis imperfecta type II and type III usually occur in people without other inherited disorders. Type III is characterized by large pulp chambers. This disturbance was connected to stages of odontoblast differentiation: if primary odontoblasts turn into odontocytes, primary dentinogenesis does not progress to secondary dentinogenesis causing type I and II dentinogenesis imperfecta meaning that odontoblasts are evergrowing.

Another genetic disorder, hypophosphataemic vitamin D-resistant rickets, is characterized by pulpal horns which extend to the enamel and by globular circumpulpal dentine in humans. The globules were normally mineralized, whereas the interspaces between the globules were not mineralized at all [24]. This suggested disturbances in dentine calcification due to disturbed phosphate homeostasis regulation. Mantle dentine below the enamel-dentine border was not globular until a width of $0.2 \mathrm{~mm}$ toward the pulp was reached [24]. Evidently, ameloblasts or Hertwig's epithelial cells resulted in the non-globular region by odontoblasts under the dentino-enamel and cementum-dentine junction.

Recent studies have identified a number of molecules with phosphaturic activities, including fibroblast growth factor-23 (FGF-23) and matrix extracellular phosphoglycoprotein [25]. FGF-23 has been implicated in various human diseases, including autosomal dominant hypophosphatemic rickets [26] and X-linked hypophosphatemia [27]. FGF-23 is mostly expressed in bone and connective tissue and prior to 2000 was known in the scientific community as phosphatonin.

\section{Enzymes in primary dentinogenesis}

A series of biochemical enzyme assays from samples taken from extracted human teeth was also performed. Samples of drilled dentine powder were taken from (1) crown enamel dentine, (2) crown dentine, (3) crown odontoblastic (circumpulpal) dentine, (4) root odontoblastic dentine, (5) apical odontoblastic dentine as well as soft carious dentine, from developing teeth and fully-formed teeth $[\underline{28}, \underline{29}]$.
APase activity was highest in all circumpulpal samples from emerged but still developing sound human teeth [28] and a dramatic drop in the activity was seen in these samples. This drop was so distinct that APase activity per protein or per wet weight of the sample was used as an indicator of the closure of the apex in clinically borderline cases: high activity represented open apex, low activity indicated the closure $[\underline{28}, \underline{29}]$.

\section{Cell function in secondary dentinogenesis}

In the adult human teeth the cell division of old odontoblasts or odontocytes is zero and their secretory activity is limited, resulting in secondary dentine formation which is very slow when compared to that of primary dentine apposition.

Odontoblasts begin as polygonal cells that leave behind processes in the dentine matrix with numerous branches. The cell bodies migrate centripetally and the process displays an increasing length. The branches are reduced near the dentine-enamel junction. They are not reminiscent of numerous lateral branches of the osteocytes within bone matrix. It was also reported that DMP1 is highly expressed in molar odontoblasts $[18,19]$.

$\mathrm{Lu}$ et al. [30] compared early and late odontoblasts with osteoblasts and osteocytes, using two osteocyte markers, DMP1, an acidic extracellular matrix protein, and E11/gp38, a transmembrane glycoprotein [31] decreased mineral deposition and lower expression of E11 and other osteocyte markers such as DMP1.

A huge difference between odontoblasts and osteocytes exists since the odontoblasts/cytes are not completely embedded in mineralized matrix like osteocytes. Osteocytes communicate between each other and with osteoblasts/bone lining cells by gap junctions found in their plasma membrane in the end their processes inside the canaliculi, which does not occur in odontoblasts in the same manner.

However, a drop in the APase activity was used as an indicator of the closure of the tooth root apex even in the crown area: high activity represented open apex, low activity indicated the closure $[\underline{28}, \underline{29}]$ and therefore, the existence of a communication system between odontoblasts is supported since some system exists linking odontoblasts in the apex and crown areas.

The remarkable similarities in morphology and the three-dimensional canalicular systems in both odontoblasts and osteocytes [30], together with a very similar expression pattern of two osteocyte markers, DMP1 and E-11, in the processes of odontoblasts 
and dendrites of osteocytes, supported the differentiation pattern of osteoblasts into osteocytes in bone. Terminally differentiated adult odontoblasts, or odontocytes [4], were found to develop an autophagic-lysosomal system organized mainly by large autophagic vacuoles that are acid-phosphatasepositive to various degrees [8]. These vacuoles expressed the autophagosomal and lysosomal markers LC3 and LAMP2 in an age-related pattern. Recently, Couve et al. [9] confirmed these observations of an autophagic-lysosomal system and additionally found mitochondrial autophagy and lipofuscin accumulation in aging odontoblasts.

\section{Enzymes in secondary dentinogenesis in sound and carious human teeth}

Histochemical methods of the localization of many enzymes in sound and carious human teeth in different developmental or pathological stages were conducted some decades ago (Figure 1). Hydrolysis of numerous naphthol derivatives was histochemically detected in the dental plaque on advanced carious lesions and in the tubules of soft carious dentine, indicating the occurrence of arylaminopeptidases [32], carboxylic ester hydrolases [33], acid phosphatase [34], phosphoamidases, pyrophosphatases, glycosidases, and arylsulphatase [35] in dentinal tubules of soft carious dentine (Figure 1). Dental plaque and dentinal tubules of carious dentine also revealed $\mathrm{LDH}$, glucose-6-phosphate, and SDH activity (Figure 1E, $1 F)$, LDH activity was demonstrable even in the area where no microorganisms (Figure 1F) were seen under the carious lesion [36].

Acid phosphatase, glucuronidase, and glycosidase substrates were observed to be hydrolyzed in the odontoblastic layer and the predentine, which area also revealed high APase and occasional succinate dehydrogenase activity. These enzymes evidently represented the host. No activity of any enzyme was demonstrated in hard dentine of sound or carious teeth $[\underline{37}, \underline{38}]$.

Quantitative enzyme activity determinations were also conducted with samples from both soft carious dentine, and from hard, pigmented carious dentine in fully-formed sound and enamel carious lesions, from teeth with dentine caries, teeth with pulpitis, and fully-formed teeth with necrotic pulps [28] Observations confirmed that APase was activated in peripulpal odontoblasts when caries was in enamel only, further activation was seen when the process reached dentine, which activation was also seen in the peripulpal area of the apex. These observations were thought to support the view that APase in the entire circumpulpal odontoblast layer reacts as a network of cells in response to caries.

Biochemical analysis of the rate of hydrolysis of arylaminopeptidase substrates revealed that enzyme activity was at least ten times higher in soft carious dentine than in non-carious coronal dentine [39]. Approximately three times as much arylaminopeptidase activity was seen in carious lesions from necrotic teeth than lesions from vital teeth which indicated that these teeth harboured different types of microbes [39]. The occurrence of aminotransferases both in sound and carious human dentine was reported, too [40] indicating degradation of amino acids during the carious process. Changes of these enzyme activities indicated that both microbial metabolism and odontoblastic response mediated the process of progression of caries in dentine.

\section{Cell function in tertiary dentinogenesis}

The most common feature of pulp repair in injury is the formation of tertiary dentine, a subgroup of which is reactionary dentine [41]. The latter generally follows a mild injury (for example carious lesions of only moderate progression), which odontoblasts survive after the stimuli. The regulation of odontoblast/cyte activity is clearly central to tooth response against injury [41].

More intense injury that later leads to odontoblast death is followed by the formation of reparative dentine. Then more complex defence and healing responses occur, with recruitment of stem or progenitor cells from pulpal origin, first reported by Gronthos et al. [42], their differentiation to odontoblast-like cells, and subsequent up-regulation of secretory activity and tissue mineralization which is called reparative dentinogenesis $[6,41,43]$. Investigation of genes and/or signaling pathways which might represent targets for the switch from secondary to tertiary dentinogenesis is important $[\underline{6}, \underline{43}]$. Dentine secretion and odontoblast activity are related to gene and cascade pathway regulation.

\section{Endopeptidases in mature human odontoblasts and pulp tissue}

A couple of decades ago it was not possible to reveal any proteolytic enzyme activity in hard, fully-formed human dentine either by histochemical or biochemical enzyme assays but soft carious dentine revealed peptidase activity [32] and endopeptidases were also demonstrable by biochemical means [44]. Therefore, with the development of more sophisticated enzyme activity assays the focus was directed to MMPs. 


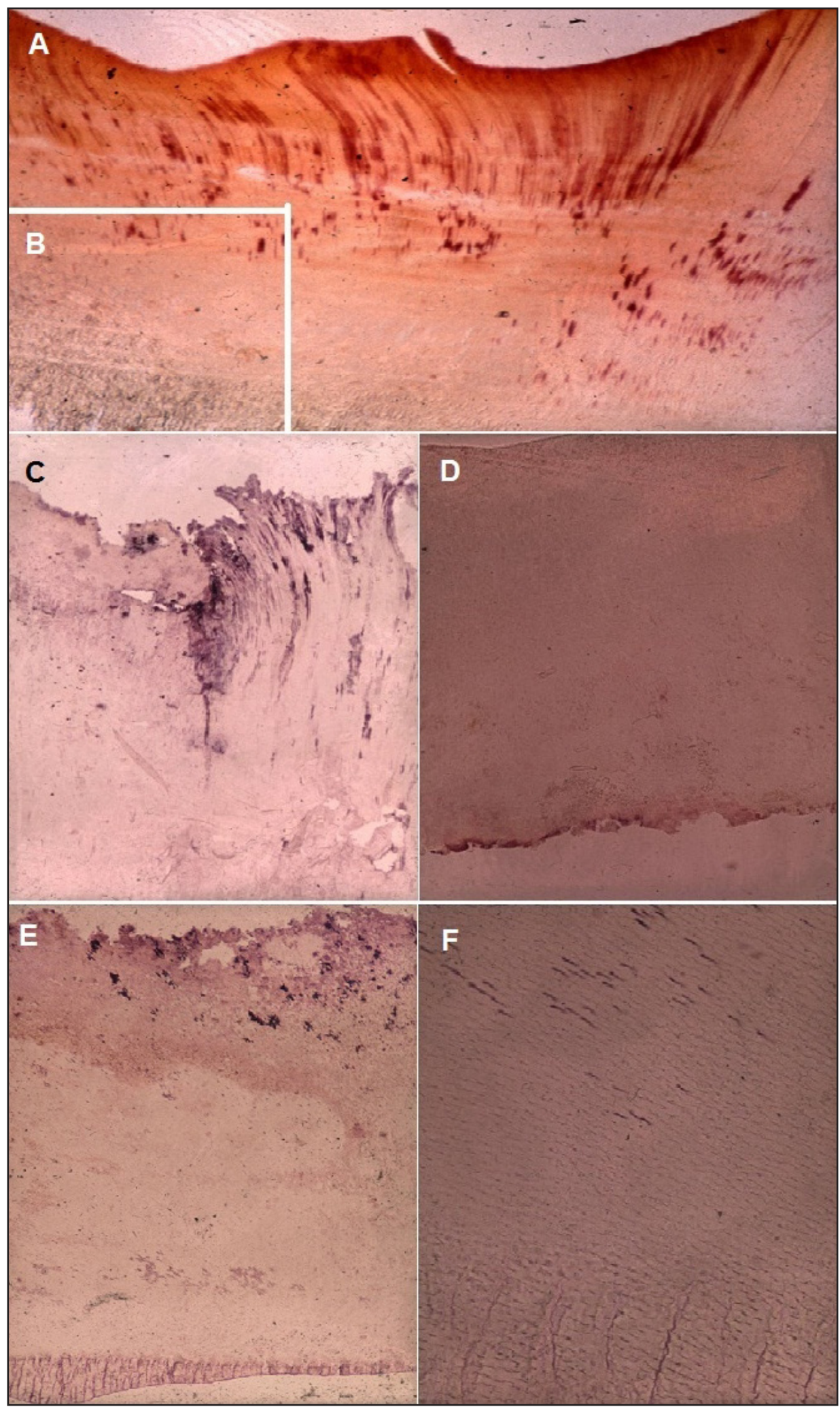

Figure 1. Examples of the presence of certain hydrolases and oxido-reductases in soft carious dentine of extracted human molar teeth. $\mathrm{A}=$ Arylaminopeptidase activity in the dentinal tubules of soft carious dentin. Substrate: L-leucyl-2-naphthylamine, Fast Blue B, pH 7.0. Original magnification $\mathrm{x} 48 . \mathrm{B}=$ Higher magnification (x165) of arylaminopeptidase on the borderland between hard (under) and soft carious dentine (above). $\mathrm{C}=$ Glocose-6-phosphate-dehyrogenase in soft carious dentine. Substrate: sodium glucose 6-phosphate, coenzyme: nitroblue tetrazolium, $\mathrm{pH}$ 8.0. Original magnification $\mathrm{x} 48 . \mathrm{D}=$ Succinate dehydrogenase in the predentine layer under a carious lesion. Substrate: sodium succinate, coenzyme: neotetrazolium, $\mathrm{pH}$ 7.8. Original magnification $\mathrm{x} 451$. E = Lactate dehyrorogenase activity in the soft carious dentine. Substrate: sodium lactate, coenzyme: NAD, nitroblue tetrazolium, $\mathrm{pH}$ 8.0. Original magnification $\mathrm{x} 48$. $\mathrm{F}=\mathrm{Higher}$ magnification (x451) of lactate dehydrogenase activity on the borderland between hard (fractured) and soft carious dentine revealing enzyme activity in dentinal tubules, ahead microorganims. The picture is reconstructed from the original slides published by Larmas et al. in Acta Odontol Scand 26: 127-136, 1968 (A and B) and Larmas in Arch oral Biol. 17: 1143-1153, 1972 (C - F). 
Activation of the proteolytic enzymes may be a critical step that leads to dentine extracellular matrix breakdown, especially in the remodelling of predentine to allow dentine formation to occur. Indeed, many MMPs are located in dentine, near the mineralization front.

First the presence of gelatinases (MMP-2, -9) was demonstrated [45] as well as collagenase-2 (MMP-8) [46] in mature healthy dentine. More detailed analysis demonstrated that MMP-14 (membrane type MMP, MT1-MMP) mRNA was expressed by native and cultured mature human odontoblasts and pulp tissue [47]. Western blot analysis of human odontoblasts and pulp tissue detected pro- and active forms of MT1-MMP, and smaller truncated MT1-MMP forms. BMP-2 down-regulated MT1-MMP expression in odontoblasts and pulp tissue, while TGF- $\beta 1$, alone or with BMP-2, decreased MT1-MMP mRNA levels only slightly. It was also demonstrated that MT1MMP was capable of converting proMMP-20 into a form corresponding to the active MMP-20.

In conclusion, observations demonstrated the expression and differential regulation of MT1MMP in human dentine-pulp complex cells, and the activation of MMP-20 by MT1-MMP. Some osteocyte markers, like BMP-2, down-regulated MMP-14 expression in mature odontoblasts while TGF- $\beta 1$ alone or with BMP-2 decreased MMP-14 mRNA levels slightly [47]. Thus, old odontoblasts/cytes share similar features with osteocytes with regard to the MMP family, which may safeguard osteoblasts from apoptosis during transdifferentiation into osteocytes.

Sulkala et al. [48] studied the presence and localization of MMP-20 in mature human teeth in health and disease. In immunohistochemistry, MMP20-positive staining was observed most intensively in the radicular odontoblastic layer and also in dilated dentinal tubuli of caries lesions. By Western blotting, MMP-20 was detected in odontoblasts and pulp tissue of both sound and carious teeth, in dentinal fluid and dentine of sound teeth, but not in soft carious dentine [48]. MMP-20 produced during primary dentinogenesis was synthesized and secreted by ameloblasts and incorporated into dentine outer layer and may be released during caries progression. The main cellular source of MMP-20 in the dentinepulp complex was the odontoblasts, which secreted MMP-20 into the dentinal fluid [47].

The FEI-SEM analysis revealed positive immunolabelling patterns for MMP-3, predominantly localized on the intertubular collagen fibrillar network showing MMP-3 directly or indirectly bound to the collagen fibrils. Casein-zymograms showed positive proteolytic activity for MMP-3 in demineralised dentine powder [어].

Dentine cysteine cathepsin and MMP activities in caries lesions were also analyzed spectrofluorometrically. Immunostaining demonstrated stronger cathepsin-B in carious than in healthy dentine. In carious dentine, cysteine cathepsin activity increased with increasing depth and age in chronic lesions, but decreased with age in active lesions. MMP activity decreased with age in both active and chronic lesions [50]. Recently it was also reported that the abundance of cysteine cathepsins and MMPs was markedly higher in caries-affected than in intact dentine. Cysteine cathepsin-B exhibited the highest percentage of co-localization with collagen, followed by MMP-9, MMP-2, and cysteine cathepsin-K. The high expression of cysteine cathepsins and MMPs in caries-affected teeth indicated that those hostderived enzymes were intensely involved with caries progression [51].

\section{Histochemical localization of APase in developing teeth with advanced dentinal caries}

When the carious process was so progressive that it reached the dental pulp in a developing human molar tooth, the histochemical distribution of APase was interesting: enzyme activity disappeared from the odontoblasts of the pulp exposure area, where cells evidently were not vital any more in these growing teeth [52]. All other odontoblasts around the pulp chamber exhibited strong APase activity, especially in the cells of the open root apices, but also periodontal structures on the root surface around the apex areas, exhibited high activity (Figure 2).

In the inflamed dental pulp, under the pulp perforation area, high APase activity was present in pulp fibroblasts or progenitor/stem cells around the inflamed area, where enzyme activity encircled the inflamed pulp horn area (Figure 2C). Only sporadic activity was seen in fibroblasts of non-inflamed pulp cells [52]. The presence of pulpal inflammation was indicated by an elevated arylaminopeptidase activity in the cells inside the inflamed pulp horn (Figure 2D). Tooth-ache was the cause of the extraction of that tooth and established the presence of inflammation and the histochemical findings [52].

It seems that APase in human dental pulp was activated by some signalling pathway either in the pulp fibroblasts or in some progenitor pulp cells or in pulp stem cells [42] under the inflamed pulp horn in a developing and elongating (growing) tooth or else, by some circulating progenitor/stem cells. What seems certain is that no APase activity occurred in the odontoblasts in the pulp exposure area, 


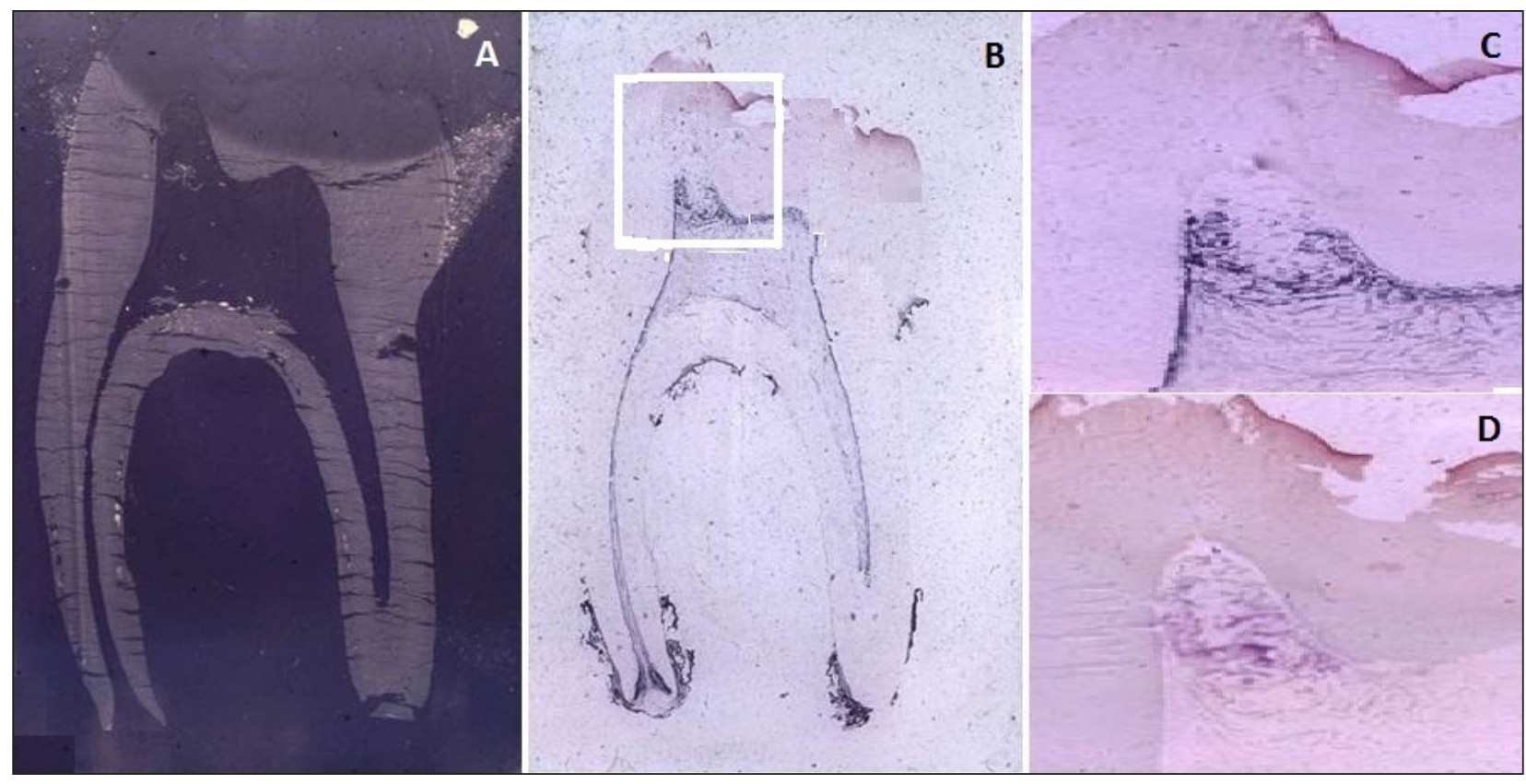

Figure 2. A = A microradiograph of a developing human molar tooth with an advanced carious lesion. Undecalcified frozen section (10 micrometer thick) of an extracted human molar tooth. Original magnification x8. B = Localization of alkaline phosphatase activity in the odontoblasts, predentine, cementum, in remaining parts of the periodontal ligament, and some pulpal cells. Substrate: 1-naphthyl acid phosphate, Fast Blue RR, pH 9.2). Original magnification x6. $\mathrm{C}=$ Higher magnification of the localization of alkaline phosphatase activity in pulpal cells under the advanced carious lesion with pulp perforation and pulpal inflammation. Note the disappearance of enzyme activity in odontoblasts in the site of carious exposure and appearance in dentinal tubules in soft carious dentin. Original magnification $\mathrm{x} 48$. $\mathrm{D}=$ Higher magnification of the same area of pulp horn showing the presence of arylaminopeptidase activity in the fibroblasts/progenitor/ stem cells or inflammatory cells in the inflamed pulp horn. Substrate: N-L-arginyl-2-naphthylamine, Fast Blue B, pH, 6.8. Original magnification x48. The picture is originally published in The Anatomical Record: Advances in Integrative Anatomy and Evolutionary Biology, 296, p. 565, 2013, and the reproduction granted by WILEY/ the Copyright Clearence Center Inc, License Number 3213520064351.

but odontoblasts in the crown or root area exhibited enzyme activity in the developing tooth, whereas pulp fibroblasts normally were without activity. In the advanced stage of carious injury, odontoblasts were non-vital and unable to produce any reactionary dentine or APase. It still remains unsolved whether pulp fibroblasts or progenitor/stem cells are capable of producing some reparative dentine, for example in the form of pulp stones.

\section{DISCUSSION}

The enzyme spectrum in differentiating and differentiated odontoblasts and in soft carious dentine is broad. Evidently most of the enzymes in carious tissue originate from microorganisms or saliva, which have penetrated into dentine. Whether these enzymes are catabolic for dentine or meant to maintain the vital functions of the microbes remains unsolved. The catabolic role of MMP enzymes was supported by the findings that dentine MMPs may participate in the destruction of dentine collagen following demineralization by bacterial acids. However, collagen is only partly destroyed, but not totally. A few collaganases are present in dentine. They initiate the action of gelatinases and non-collagenous proteins are destroyed. The presence of lactate dehydrogenase deep in the carious lesion suggests that the production of lactic acid is possible there and enables the dissolution of the dentine wall perpendicular to dentinal tubules and thereby their dilation, which explains the undermining appearance found in carious lesions [37]. The localization and activation of APase in odontoblasts and pulpal fibroblasts or progenitor cells point to the role of APase in cell differentiation during dentine formation. Stem cell-based tooth regeneration is a promising approach to solving the problems of dentine caries and human skeletal muscle stem cells could also differentiate into odontoblasts but required an extracellular matrix scaffold and changes in their integrin profile that was evidenced by appearance of odontoblastic phenotypes [53]. Therefore, cellular responses of pulpal origin against dental caries seem evident.

\section{CONCLUSIONS}

Though dental studies are scanty when compared to bone, the active role of large spectrum of enzymes in healthy and carious dentine was given support. 


\section{ACKNOWLEDGMENTS AND DISCLOSURE STATEMENTS}

The authors report no conflicts of interest related to this review article.

\section{REFERENCES}

1. Sinanan AC, Hunt NP, Lewis MP. Human adult craniofacial muscle-derived cells: neural-cell adhesion-molecule (NCAM; CD56)-expressing cells appear to contain multipotential stem cells. Biotechnol Appl Biochem. 2004 Aug;40(Pt 1):25-34. [Medline: 15270704]

2. Goldberg M, Smith A. Cells and extracellular matrices of dentin and pulp: A biological basis for repair and tissue engineering. Cri Rev Oral Biol Med. 2004 Jan;15(1):13-27. [Medline: 14761897] [doi: 10.1177/154411130401500103]

3. Jo YY, Lee HJ, Kook SY, Choung HW, Park JY, Chung HJ, Choung YH, Kim ES, Yang HC, Choung PH. Isolation and characterization of postnatal stem cells from human dental tissues. Tiss Engin. 2007 Apr;13(4):767-73. [Medline: 17432951] [doi: 10.1089/ten.2006.0192]

4. Larmas MA, Sándor GK. The bedrock of science. Similarities and dissimilarities in phenomena and cells of tooth and bone ontogeny. Anat Record. Adv Hoboken. 2013 Apr;296(4):564-7. [Medline: 23420639] [doi: 10.1002/ar.22671]

5. Simon SRJ, Berdal A, Cooper PR, Lumley PJ, Tomson PL, Smith AJ. Dentin-Pulp Complex Regeneration: from Lab to Clinic. Adv Dent Res. 2011 Jul;23(3):340-5. [Medline: 21677089] [doi: 10.1177/0022034511405327]

6. Ten Cate AR. Dentinogenesis. In: Ten Cate AR. Oral histology, development, structure, and function. Mosby, St Louis, Baltimore, Toronto; 1994.

7. Couve E. Ultrastructural changes during the life cycle of human odontoblasts. Arch Oral Biol. 1986;31(10):643-51. [Medline: 3477208] [doi: 10.1016/0003-9969(86)90093-2]

8. Couve E, Schmachtenberg O. Autophagic activity and aging in human odontoblasts. J Dent Res. 2011 Apr;90(4):523-8. [Medline: 21212314] [doi: 10.1177/0022034510393347]

9. Couve E, Osario R, Schmahtenberg O. Mitochondrial autophagy and lipofuscin accumulation in aging odontoblasts. J Dent Res. 2012 Jul;91(7):696-701. [Medline: 22622661] [doi: 10.1177/0022034512449347]

10. Liberati A, Altman DG, Tetzlaff J, Mulrow C, Gotzsche PC, Ioannidis JP, Clarke M, Devereaux PJ, Kleijnen J, Moher D. The PRISMA statement for reporting systematic reviews and meta-analyses of studies that evaluate health care interventions: explanation and elaboration. J Clin Epidemiol 2009 Oct;62(10): e1-34. [Medline: 19631507] [doi: 10.1016/j.jclinepi.2009.06.006]

11. Higgins JPT, Green S. Cochrane handbook for systematic reviews of interventions version 5.1.0. The Cochrane Collaboration, 2011 [updated March 2011]. [URL: http://www.cochrane.org/handbook]

12. Hiller CR, Robinson C, Weatherell JA. Variations in the composition of developing rat incisor enamel. Cal Tis Res. 1975 Jul;18(1):1-12. [Medline: 1148889] [doi: 10.1007/BF02546222]

13. Larmas L, Larmas M. A histochemical study of hydrolytic enzymes in human tooth ontogeny. J Periodont Res. 1974;9(1):29-38. [Medline: 4277334] [doi: 10.1111/j.1600-0765.1974.tb00650.x]

14. Larmas L, Larmas M. A histochemical study of various dehydrogenases in human tooth ontogeny. Arch Oral Biol. 1976;21(6):371-7. [Medline: 1066116] [doi: 10.1016/S0003-9969(76)80005-2]

15. Larmas M, Thesleff I. Biochemical study of changes in non-specific alkaline phosphomonoesterase activity during mouse tooth ontogeny. Arch Oral Biol. 1980;25(11-12): 791-7. [Medline: 6944000] [doi: 10.1016/0003-9969(80)90136-3]

16. Sahlberg C, Reponen P, Tryggvason K, Thesleff I. Timp-1, -2 and -3 show coexpression with gelatinases A and B during mouse tooth morphogenesis. Eur J Oral Sci. 1999 Apr;107(2):121-30. [Medline: 10232461] [doi: 10.1046/j.0909-8836.1999.eos107208.x]

17. Hietala E-L, Larmas M, Salo T. Localization of estrogen-receptor-related antigen in human odontoblasts. J Dent Res. 1998 Jun;77(6):1384-7. [Medline: 9649166$]$ [doi: 10.1177/00220345980770060201]

18. Feng JQ, Zhang J, Dallas SL, Lu Y, Chen S, Tan X, Owen M, Harris SE, MacDougall M. Dentin matrix protein 1, a target molecule for Cbfa1 in bone, is a unique bone marker gene. J Bone Mine Res. 2002 Oct;17(10):1822-31. [Medline: 12369786] [doi: 10.1359/jbmr.2002.17.10.1822]

19. Feng JQ, Huang H, Lu Y, Ye L, Xie Y, Tsutsui TW, Kunieda T, Castranio T, Scott G, Bonewald LB, Mishina Y. The dentin matrix protein 1 (Dmp1) is specifically expressed in mineralized, but not soft tissues during development. J Dent Res. 2003 Oct;82(10):776-80. [Medline: 14514755] [doi: 10.1177/154405910308201003]

20. Lin H, Xu L, Liu H, Sun Q, Chen Z, Yuan G, Chen Z. KLF4 promotes the odontoblastic differentiation of human dental pulp cells. J Endo. 2011 Jul;37(7):948-54. [Medline: 21689550] [doi: 10.1016/j.joen.2011.03.030]

21. Larmas M, Kortelainen S. Quantification of the areas of dentinal lesions and secondary dentin in fissures of rat molars. Caries Res. 1989;23(1):32-5. [Medline: 2465824] [doi: 10.1159/000261151] 
22. Kortelainen S, Larmas M. Effect of fluoride on the rate of dentin apposition and caries progression in young and old Wistar rats. Scand J Dent Res. 1994 Feb;102(1):30-3. [Medline: 8153575]

23. Larmas M. Dental caries seen from the pulpal side: a non-traditional approach. J Dent Res 2003 Apr;82(4): 253-6. [Medline: 12651926] [doi: 10.1177/154405910308200402]

24. Hietala E-L, Larmas MA. Mineral content of different areas of human dentin in hypophosphataemic vitamin D-resistant rickets. Jour Biol Buc. 1991 Jun;19(2):129-34. [Medline: 1657902]

25. Quarles LD. FGF23, PHEX, and MEPE regulation of phosphate homeostasis and skeletal mineralization. Am J Phys Endocrino Metabol. 2003 Jul;285(1):E1-E9. [Medline: 12791601]

26. ADHR Consortium. Autosomal dominant hypophosphataemic rickets is associated with mutations in FGF23. Nature Gen. 2000;26:345-8. [Medline: 11062477 ] [doi: $10.1038 / 81664]$

27. Yamazaki Y, Okazaki R, Shibata M, Hasegawa Y, Satoh K, Tajima T, Takeuchi Y, Fujita T, Nakahara K, Yamashita T, Fukumoto S. Increased circulatory level of biologically active full-length FGF-23 in patients with hypophosphatemic rickets/osteomalacia. J Clin Endocrino Metabol. 2002 Nov;87(11):4957-60. [Medline: 12414858] [doi: $10.1210 /$ jc. 2002-021105]

28. Läikkö I, Larmas M. Phosphomonoesterase activity in dentine of sound and carious human teeth. Caries Res. 1978;12(3):148-58. [Medline: 204411] [doi: 10.1159/000260325]

29. Läikkö I, Larmas M. Changes of phosphomonoesterase activity in human dentine during the formation of the root of the tooth. J Dent Res. 1980 Oct;59(11):1558-64. [Medline: 6932411] [doi: 10.1177/00220345800590100101]

30. Lu Y, Xie Y, Zhang S, Dusevich V, Bonevald LF, Feng JQ. DMP1-targeted Cre expression in odontoblasts and osteocytes. J Dent Res. 2007 Apr;86(4):320-5. [Medline: 17384025] [doi: 10.1177/154405910708600404]

31. Zhang K, Barragan-Adjemian C, Ye L, Kotha S, Dallas M, Zhao S, Harris M, Harris SE, Feng JQ, Bonewald LF. E11/ gp38 selective expression in osteocytes: regulation by mechanical strain and role in dendrite elongation. Mol Cell Biol. 2006 Jun;26(12):4539-52. [Medline: 16738320] [PMC free article: 1489126] [doi: 10.1128/MCB.02120-05]

32. Larmas M, Mäkinen KK. Histochemical demonstration of enzymes hydrolyzing N-L-arginyl and N-L-prolylnaphthylamine in human carious dentine. Caries Res. 1972;6(1): 50-5. [Medline: 4502176] [doi: 10.1159/000259771]

33. Larmas M. A chromatographic and histochemical study of nonspecific esterases in human carious dentine. Arch Oral Biol. 1972 Aug;17(8):1121-32. [Medline: 4506795] [doi: 10.1016/0003-9969(72)90083-0]

34. Mäkinen KK, Larmas MA, Scheinin A. Activity of arylaminopeptidases, phosphatases, and L-cystine cleaving enzymes in normal and carious human dentine. Caries Res. 1969;3(2):134-48. [Medline: 4316010] [doi: 10.1159/000259577]

35. Larmas M. Histochemical studies on enzymes acting on glycosyl compounds, phosphoryl-containing anhydrides and phosphoamides in human carious dentine. Acta Odont Scand. 1972 May;30(2):201-18. [Medline: 4262582] [doi: 10.3109/00016357208997460]

36. Larmas M. Histochemical demonstration of various dehrogenases in human carious dentine. Arch Oral Biol. 1972 Aug;17(8):1143-53. [Medline: 4506797] [doi: 10.1016/0003-9969(72)90085-4]

37. Larmas M. Odontoblast function seen as the response of dentinal tissue to dental caries. Adv Dent Res. 2001 Aug;15:6881. [Medline: 12640744$]$ [doi: $10.1177 / 08959374010150011701]$

38. Larmas M, Kortelainen S, Bäckman T, Hietala EL, Pajari U. Odontoblast-mediated regulation of the progression of dentinal caries. Proc Finn Dent Soc. 1992;88 Suppl 1:313-20. [Medline: 1508887]

39. Karjalainen S, Larmas M. Quantitative study of the arylaminopeptidase activity in normal and altered states of human dentine. Caries Res. 1975;9(5):340-50. [Medline: 1055637] [doi: 10.1159/000260167]

40. Larmas M. Alanine and aspartate aminotransferases in sound and carious human dentine. Arch Oral Biol. 1972 Aug;17(8):1133-41. [Medline: 4506796] [doi: 10.1016/0003-9969(72)90084-2]

41. Smith AJ, Cassidy N, Perry H, Bègue-Kirn C, Ruch JV, Lesot H. Reactionary dentinogenesis. Int J Develop Biol. 1995 Feb;39(1):273-80. [Medline: 7626417]

42. Gronthos S, Mankani M, Brahim J, Robey PG, Shi S. Postnatal human dental pulp stem cells (DPSCs) in vitro and in vivo. Proc Nat Acad Sci (USA). 2000 Dec;97(25):13625-30. [Medline: 11087820] [PMC free article: 17626] [doi: 10.1073/pnas.240309797]

43. Simon SRJ, Smith AJ, Lumley PJ, Berdal A, Smith G, Finney S, Cooper PR. Molecular characterization of young and mature odontoblasts. Bone. 2009 Oct;45(4):693-703. [Medline: 19555781] [doi: 10.1016/j.bone.2009.06.018]

44. Larmas M. Observations on endopeptidases in human carious dentin. Scand J Dent Res. 1972;80(6):520-3. [Medline: 4196471]

45. Tjäderhane L, Larjava $H$, Sorsa $T$, Uitto VJ, Larmas M, Salo T. The activation and function of host matrix metalloproteinases in dentin matrix breakdown in caries lesions. J Dent Res. 1998 Aug;77(8):1622-29. [Medline: 9719036] [doi: 10.1177/00220345980770081001]

46. Palosaari H, Wahlgren J, Larmas M, Sorsa T, Salo T, Tjäderhane L. The expression of MMP-8 in human odontoblasts and dental pulp cells is down-regulated by TGF-beta1. J Dent Res. 2000 Jan;79(1):77-84. [Medline: 10690664] [doi: 10.1177/00220345000790011401]

47. Palosaari H, Ding Y, Larmas M, Sorsa T, Bartlett JD, Salo T, Tjäderhane L. Regulation and interactions of MT1-MMP and MMP-20 in human odontoblasts and pulp tissue in vitro. J Dent Res. 2002 May;81(5):354-9. [Medline: 12097451] [doi: $10.1177 / 154405910208100513$ ] 
48. Sulkala M, Larmas M, Sorsa T, Salo T, Tjäderhane L. The localization of matrix metalloproteinase-20(MMP-20, enamelysin) in mature human teeth. J Dent Res. 2002 Sep;81(9):603-7. [Medline: 12202640] [doi: 10.1177/154405910208100905]

49. Mazzoni A, Papa V, Nato F, Carrilho M, Tjäderhane L, Ruggeri A Jr, Gobbi P, Mazzotti G, Tay FR, Pashley DH, Breschi L. Immunohistochemical and biochemical assay of MMP-3 in human dentine. J Dent. 2011 Mar;39(3): 231-7. [Medline: 21215789] [PMC free article: 3815524] [doi: 10.1016/j.jdent.2011.01.001]

50. Nascimento FD, Minciotti CL, Geraldeli S, Carrilho MR, Pashley DH, Tay FR, Nader HB, Salo T, Tjäderhane L, Tersariol IL. Cysteine cathepsins in human carious dentin. J Dent Res. 2011 Apr;90(4):506-11. [Medline: 21248362] [PMC free article: 3144127 ] [doi: 10.1177/0022034510391906]

51. Vidal CM, Tjäderhane L, Scaffa PM, Tersariol IL, Pashley D, Nader HB, Nascimento FD, Carrilho MR. Abundance of MMPs and cysteine cathepsins in caries-affected dentin. J Dent Res. 2014 Mar;93(3):269-74. [Medline: 24356440] [doi: $10.1177 / 0022034513516979]$

52. Larmas M, Kantola S. A histochemical study of arylaminopeptidases and alkaline phosphatases in sound and carious human teeth. Acta Odont Scand. 1973;31(3):179-85. [Medline: 4520574] [doi: 10.3109/00016357309002503]

53. Ozeki N, Mogi M, Yamaguchi H, Hiyama T, Kawai R, Hase N, Nakata K, Nakamura H, Kramer RH. Differentiation of human skeletal muscle stem cells into odontoblasts is dependent on induction of $\alpha 1$ integrin expression. J Biol Chem. 2014 Apr;289:14380-91. [Medline: 24692545] [doi: 10.1074/jbc.M113.526772]

\section{To cite this article:}

Larmas M, Sándor GK. Enzymes, Dentinogenesis and Dental Caries: a Literature Review.

J Oral Maxillofac Res 2014;5(4):e3

URL: http://www.ejomr.org/JOMR/archives/2014/4/e3/v5n4e3ht.pdf

doi: $10.5037 /$ jomr.2014.5403

Copyright (C) Larmas M, Sándor GK. Published in the JOURNAL OF ORAL \& MAXILLOFACIAL RESEARCH (http://www.ejomr.org), 29 December 2014.

This is an open-access article, first published in the JOURNAL OF ORAL \& MAXILLOFACIAL RESEARCH, distributed under the terms of the Creative Commons Attribution-Noncommercial-No Derivative Works 3.0 Unported License, which permits unrestricted non-commercial use, distribution, and reproduction in any medium, provided the original work and is properly cited. The copyright, license information and link to the original publication on (http://www.ejomr.org) must be included. 